\title{
Pre and Post-Treatment Effects: Estimation of Serum Testosterone and Lipid Peroxidation Levels on Moringa olifera Extract Induced Cadmium Exposed Rats
}

\author{
Pratik Kumar Chatterjee, Vinodini Nithyananda Madom Anantharaya*, Rashmi Kaup Shiva, Nayanatara Arun \\ Kumar, Sneha Bhoja Shetty, Suman Veerappa Budihal, Mangalore Ramesh Bhat, Kunal
}

\section{Pratik Kumar Chatterjee, Vinodini Nithyananda Madom Anantharaya, Rashmi Kaup Shiva, Nayanatara Arun Kumar, Sneha Bhoja Shetty, Suman Veerappa Budihal, Mangalore Ramesh Bhat, Kunal \\ Department of Physiology, \\ Kasturba Medical College (KMC) \\ Mangalore-575004, Manipal University \\ (MU), Karnataka, INDIA \\ Correspondence}

Dr. Vinodini Nithyananda Madom Anantharaya

Department of Physiology, Kasturba Medical College (KMC), Mangalore-575004, Manipal University (MU), Karnataka, INDIA.

Phone no: (+91) 9448214870

E-mail: vinodini.na@manipal.edu

History

- Submission Date: 07-07-2017;

- Review completed: 28-07-17.

- Accepted Date: 22-08-2017.

DOI : 10.5530/pj.2017.6.132

Article Available online

http://www.phcogj.com/v9/i6

Copyright

(C) 2017 Phcog.Net. This is an openaccess article distributed under the terms of the Creative Commons Attribution 4.0 International license.

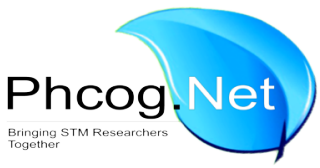

\begin{abstract}
Background: Cadmium ( $\mathrm{Cd}$ ), is a toxic metal which affects various organs including testis It produces oxidative stress leading to male infertility. Moringa tree, is a natural plant with a great therapeutic value and hence it is found to be effective both in prevention and treatment of various conditions including reducing toxicity of hazardous materials. The aim of the present study was to examine the effects of Pre-and Post-treatment with Moringa oliefera leaf extract (MoE) on testis in cadmium exposed rats. Materials and Methods: The present study was conducted at the Department of Physiology, Kasturba Medical College (KMC), Mangalore, Manipal University (MU), Karnataka, India, between (2011-2013). This prospective study consisted a total of 30 rats. These were divided into 5 groups with group I being the control. Data were presented as mean \pm SD. student's $t$ test was used as statistical tool, $p<0.05$ considered statistically significant. Group IV and V were pre-and post-MoE treated groups respectively. Serum testosterone and tissue lipid peroxidation levels were estimated. Results: Treatment with MoE prior and after administration of cadmium, respectively showed an increase significantly in the testosterone levels and a decrease in the tissue lipid peroxidation as compared to the group treated with cadmium. However, the pre-treatment showed better results in combatting the toxic effects of cadmium. Conclusion: This study shows that Moringa olifera leaf extract altered the testosterone and tissue lipid peroxidation levels. Also, pre-treatment showed better outcome.

Key words: Cadmium, MDA, Testosterone, Oxidative stress, Morniga olifera extract.
\end{abstract}

\section{INTRODUCTION}

Cadmium has been found to produce various dysfunctions in our body, physiologically and biochemically. It can also lead to injury to the tissues. ${ }^{1}$ Previous studies have shown that one of several mechanisms through which cadmium exerts its toxicity is by altering the antioxidant defence systems and increasing the production of cellular reactive oxygen species, like singlet oxygen, hydrogen peroxide and hydroxyl radicals. ${ }^{2}$ This is usually followed by the development of oxidative stress in the target organs. ${ }^{3,4}$ Cadmium toxicity affects many organs adversely like, kidney, liver, lung, pancreas, prostate, ovaries, placenta etc. including testis. ${ }^{5,6}$ Moringa oleifera of Moringaceae family is one of the plant species that provide medicinal herbs which has been scientifically evaluated for its possible medicinal applications. ${ }^{7}$ Cadmium toxicity leads to alterations in the antioxidant defense system by fetching changes in the lipid peroxidation levels. ${ }^{8}$ Moringa oleifera is considered as a highly nutritious herb which has a lot of medicinal values and source of vitamins, minerals and other phytochemicals with antioxidant property. ${ }^{7}$ Hence, extracts of this plant is indicated as an anti-cancer, anti-inflammatory and hepato-protective agent., ${ }^{9,10}$ Its anti-diabetic actions also has been demonstrated. Till recent times, there are ongoing scientific researches being carried on some of the reported medicinal properties of this plant.

Male infertility is one of the important problems nowadays and affects almost about $10 \%$ of couples in the society. Recently there are few studies reported on Moringa oleifera in improving the fertility rate. A study done by the Bureau of Plant Industry (BPI) revealed that the sperm count in men can be boosted by a steady diet of Moringa fruit. ${ }^{12,13}$ But till date there are no studies reported the comparative results Moringa olifera prior and after the treatment on serum testosterone and tissue lipid peroxidation levels in cadmium exposed rats. So, the present study was designed to elucidate the effect of

Cite this article: Chatterjee PK, Vinodini NA, Rashmi KS, Nayanatara AK, Shetty SB, Suman VB Bhat R, Kunal. Pre and Post-Treatment Effects: Estimation of Serum Testosterone and Lipid Peroxidation Levels on Moringa olifera Extract Induced Cadmium Exposed Rats. Pharmacog J. 2017;9(6):846-9. 
extract of Moringa oliefera leaf on damage of testicles after the exposure of cadmium in wistar rats.

\section{MATERIALS AND METHODS}

The chemicals required for the biochemical assay were obtained from Durga Laboratories, India. Experiments were carried out after approval from the Institutional Animal Ethics Committee (IAEC).

\section{Preparation of Extract}

The leaves were collected and validated by a taxonomist. After drying the leaves at $37^{\circ} \mathrm{C}$, powdered form of extract was prepared. $20 \mathrm{gm}$ of powder was soaked in $100 \mathrm{ml}$ of water and chloroform in a shaker for three days. It was further concentrated Filtrate of this was concentrated to $10 \%$ of its original. We concentrated the filtrate in rotary evaporator and dried in water bath. ${ }^{14}$

We procured male Wistar Albino rats (4 months old) from the institutional animal house. They were provided food and water adlibitum. Rats were maintained and procedures were conducted according to the institutional ethical committee guidelines.

\section{Experimental Design}

The present study was conducted at the Department of Physiology, Kasturba Medical College (KMC), Mangalore, Manipal University (MU), Karnataka, India. A total of 30 male Wistar rats were divided into five (5) groups as summarized in the Table below. ${ }^{4}$

\section{Hormonal Assay}

Tesosterone was estimated in $2 \mathrm{ml}$ of blood which was collected from rats by cardiac puncture. Chemiluminescence Immuno Assay (CLIA) kit (Chen et al,1991) was used for the estimation of serum testosterone levels. ${ }^{15}$

Tissue lipid peroxidation (MDA) was analysed by using testis tissue hemosylate. Malondialdehyde was estimated by the standard procedure described by Kartha and Krishnamurthy. ${ }^{16}$

\section{Statistical Analysis}

Data were presented as mean \pm SD. Student's t test was used as statistical tool, $\mathrm{p}<0.05$ considered statistically significant.

\section{RESULTS}

Results depicted in Figure 1, show prior and post treatment with aqueous Moringa olifera leaf extract on tissue lipid peroxidation level and serum testosterone level. A significant decrease in testosterone and increase lipid peroxidation $(\mathrm{MDA})$ was observed $(\mathrm{p}<0.0001)$ in cadmium treated group when compared to the control and pre-and post-treated M. oliefera

\begin{tabular}{|c|c|}
\hline GROUPS $(n=6)$ & \\
\hline $\begin{array}{c}\mathrm{I} \\
\text { (Control) }\end{array}$ & Orally administered $0.9 \%$ saline \\
\hline $\begin{array}{c}\text { II } \\
\text { (Experimental control) }\end{array}$ & $\begin{array}{l}\text { Orally infused with M. oleifera extract, } 100 \mathrm{mg} / \\
\mathrm{kg} / \mathrm{bw} \text { for } 10 \text { days }\end{array}$ \\
\hline III & $\begin{array}{l}\text { Received a single oral dose of cadmium chloride } \\
\qquad(10 \mathrm{mg} / \mathrm{kg} / \mathrm{bw})\end{array}$ \\
\hline IV & $\begin{array}{l}\text { Treated with M. oleifera leaf extract }(100 \mathrm{mg} / \mathrm{kg} / \\
\text { bw) for } 10 \text { days, followed by cadmium chloride } \\
(10 \mathrm{mg} / \mathrm{kg} / \mathrm{bw}) \text { given orally for one day }\end{array}$ \\
\hline $\mathrm{V}$ & $\begin{array}{l}\text { Oral infusion of single dose of } \mathrm{CdCl}(10 \mathrm{mg} / \\
\mathrm{kgbw}) \text { followed by Moringa olifera leaf extract } \\
(100 \mathrm{mg} / \mathrm{kgbw}) 10 \text { days }\end{array}$ \\
\hline
\end{tabular}

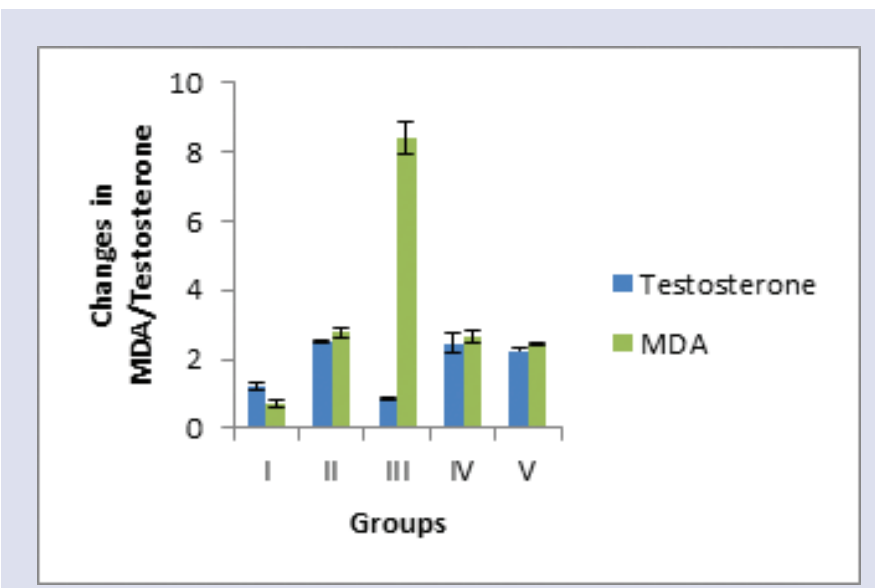

Figure 1: Changes in the MDA \& testosterone level with prior \& posttreatment with MoE in Cadmium exposed rats. Values are expressed in mean \pm SD.

leaf extract (MoE). Highly significant decrease in lipid peroxidation of testis and significant increase in testosterone levels were observed when group IV and group V was compared to group III.

\section{DISCUSSION}

Effect of heavy metal exposure on testes (biology of reproduction) has become one of the major concern for the society as it is directly related to infertility. ${ }^{17,18,19}$ Recently, anti-diabetic actions of Moringa olifera have also been reported. ${ }^{20}$ Cadmium is a toxic metal, implicated in oxidative stress ${ }^{10,11}$ and embryonic tissue. ${ }^{21,22}$ Oxidative stress arises from a variance between the production of oxidants and physiological antioxidant capability. ${ }^{23}$ Lipid peroxidation is a measure of oxidative stress. Hence in the present experiment we measured tissue lipid peroxidation and serum testosterone levels. ${ }^{23}$ Our results showed significant increase in the testicular MDA of the cadmium alone treated group (oral $10 \mathrm{mg} / \mathrm{kg} / \mathrm{bw}$, single dose). Testosterone levels were found to be decreased significantly in these rats. These findings indicate testicular toxicity. Our previous study reports on Pre- treatment of Moringa olifera in rats also showed the similar results on cadmium induced rats. ${ }^{24}$ Imbalance of steroidogenic activity observed in this study are in accordance with the previous reports. ${ }^{25,26}$ Increased MDA level suggests that $\mathrm{CdCl} 3$ triggered testicular oxidative damage by enhancing the production of reactive oxygen species. ${ }^{27}$ Treatment with M. oleifera (pre and post $100 \mathrm{mg} / \mathrm{kg}$ oral for 10 days ) showed decreased toxic effect caused due to exposure of cadmium, which is evidenced by an increase in the serum testosterone level coupled with decrease in the tissue MDA levels. However, the pretreated group showed a better effect in reducing the toxicity than the treated group after exposure to cadmium M. oleifera leaf extract (proved of having bio flavonoid and other effective antioxidants) administration prior to cadmium exposure and post to cadmium exposure caused in significant improvement of toxicity in the testis. ${ }^{9,10}$ Studies have also reported that pre-treatment with $M$. oleifera leaf extract (containing fundamental antioxidant and phenolic compounds) protects the testes against various lethal substances and the oxidative damage caused by them ${ }^{26}$ Our study suggest that Moringa oleifera extract could diminish cadmium induced toxicity which owe to their antioxidant property. This may explain the fact that, the experimental group treated cadmium and $M$. oliefera leaf extract $(\mathrm{MoE})$ showed an increase in testosterone concentration and subsequent reduc- 
tion in testicular MDA. Studies have shown antioxidant activities of $M$. oleifera leaves. ${ }^{28}$ Active components of this plant scavenge free radicals. It offers protection against oxidative damage on cellular macro molecules. Free radical scavengers may include polyphenols, flavonoids, and phenolic compounds. ${ }^{29}$ Moringa oleifera could enhance the antioxidant system present in the epididymis which in turn preserved and facilitated the process of spermatogenesis. Apparently, it may have reversed concentrations of gonadotropins (FSH and $\mathrm{LH}$ ) and ultimately testosterone. ${ }^{30}$ Therefore the present study suggests that $M$. oleifera leaf extract (MoE) can be used as preventive and convalescent agent to attenuate the deleterious effects of cadmium on the testis

\section{CONCLUSION}

Plant extract used in the present study offers a cheap alternative therapeutic potential in treating cadmium induced testicular damage and infertility.

\section{Limitation of the Study}

Further studies are warranted in isolating the active components responsible for the reversal of cadmium induced decrease in sex hormone and testicular damage.

\section{ACKNOWLEDGEMENT}

We are thankful to Manipal-University (MU), Karnataka, India, for supporting the Research work. We are also thankful to the Department of Physiology, Kasturba Medical College (KMC), Mangalore, Manipal-University (MU), Karnataka, India, for providing the laboratory \& necessary instruments for conducting the experiments.

\section{CONFLICT OF INTEREST}

No conflict of interest are declared.

\section{ABBREVIATION USED}

MOE: Moringa olifera extract; FSH: Follicular Stimulating Hormone;

LH: Leutinizing Hormone.

\section{REFERENCES}

1. Gaurav D, Preet S, Dua KK. Chronic cadmium toxicity in rats: treatment with combined administration of vitamins, amino acids, antioxidants and essentia metals. Journal of Food and Drug Analysis (JFDA). 2010;18(6):464-70

2. Singh $P$, Deora K, Bano $H$, Mogra $P$, Javeria S, Barolia S. Protective effect of curcumin on cadmium chloride induced epididymal toxicity in Swiss mice (Mus musculus). Journal of Chemical, Biological and Physical Sciences (JCBPS). 2012;2(2):797

3. Santos FW, Oro T, Zeni G, Rocha JB, do Nascimento PC, Nogueira CW. Cadmium induced testicular damage and its response to administration of succimer and diphenyl diselenide in mice. Toxicology letters (TL). 2004;152(3):255-63

4. Valko M, Rhodes CJ, Moncol J, Izakovic MM, Mazur M. Free radicals, metals and antioxidants in oxidative stress-induced cancer. Chemico-biological interactions (CBI). 2006;160(1):1-40

5. Vinodini NA, Chatterjee PK, Rakshatha R, Singh RR, Amemarsoofi A, Kini RD, et al. Role of Moringa oliefera leaf extract in protecting cadmium induced testicular damage in male Wistar Albino rats. The Journal of Free Radicals and Antioxidants (JFRA)-Photon Journals. 2013;139:135-40

6. Waisberg M, Joseph $\mathrm{P}$, Hale B, Beyersmann D. Molecular and cellular mechanisms of cadmium carcinogenesis. Toxicology. 2003;192(2):95-117

7. Diallo A, Eklu-Gadegkeku K, Mobio T, Moukha S, Agbonon A, Aklikokou K, et al. Protective effect of Moringa oleifera Lam. and Lannea kerstingii extracts against cadmium and ethanol-induced lipid peroxidation. Journal of Pharmacology and Toxicology (JPT). 2009;4(4):160-6

8. Roopashree Mallya, Pratik Kumar Chatterjee, Navinodini, Poulomi Chatterjee, Prasanna Mithra. Moringa oleifera Leaf Extract: Beneficial Effects on Cadmium Induced Toxicities - A Review. Journal of Clinical and Diagnostic Research (JCDR). 2017;11(4):CE01-CE04

9. Chatterjee PK, Anantharaya VN, Singhal A, Chatterjee P, Shiva RK, Mallya R. Moringa oleifera aqueous leaf extract: role on total leucocyte count and its differentials in cadmium toxicity in adult Wistar Albino rat model. National Journal of Physiology, Pharmacy and Pharmacology (NJPPP). 2016;6(2):119-22

10. Ashok KN, Pari L. Antioxidant action of Moringa oleifera Lam.(drumstick) against antitubercular drugs induced lipid peroxidation in rats. Journal of Medicinal Food (JMF). 2003;6(3):255-9

11. Fahey JW. Moringa oleifera: a review of the medical evidence for its nutritional, therapeutic, and prophylactic properties. Part 1. Trees for life Journal (TLJ) 2005; 1(5):1-5

12. Cajuday LA, Pocsidio GL. Effects of Moringa oleifera Lam.(Moringaceae) on the reproduction of male mice (Mus musculus). Journal of Medicinal Plants Research (JMPR). 2010;4(12):1115-21

13. Dhama K, Tiwari R, Chakraborty S, Saminathan M, Kumar A, Karthik K, et al. Evidence based antibacterial potentials of medicinal plants and herbs countering bacterial pathogens especially in the era of emerging drug resistance: An integrated update. Int J Pharmacol (IJP). 2014;10(1):1-43

14. Patwardhan B, Bodeker G. Ayurvedic genomics: establishing a genetic basis for mind-body typologies. The Journal of Alternative and Complementary Medicine (JACM). 2008;14(5):571-6

15. Chen A, Bookstein JJ, Meldrum DR. Diagnosis of a testosterone-secreting adrenal adenoma by selective venous catheterization. Fertility and sterility (FS). 1991;55(6):1202-3

16. Kartha VN, Krishnamurthy S. Factors affecting in vitro lipid peroxidation of rat brain homogenate. Indian journal of physiology and pharmacology (IJPP). 1977;22(1):44-52

17. Borges LP, Brandão R, Godoi B, Nogueira CW, Zeni G. Oral administration of diphenyl diselenide protects against cadmium-induced liver damage in rats. Chemico-biological interactions (CBI). 2008;171(1):15-25

18. Kaplan M, Atakan IH, Aydogdu N, Aktoz T, Özpuyan F, Seren G, et al. Influence of $\mathrm{N}$-acetylcysteine on renal toxicity of cadmium in rats. Pediatric Nephrology (PN). 2008;23(2):233-41

19. Ognjanovic BI, Markovic SD, Pavlovic SZ, Zikic RV, Stajn AS, Saicic ZS. Effect of chronic cadmium exposure on antioxidant defense system in some tissues of rats: protective effect of selenium. Physiological Research (PR). 2008;57(3):403

20. Shukla R, Kumar M. Role of Panax ginseng as an antioxidant after cadmiuminduced hepatic injuries. Food and Chemical Toxicology (FTC). 2009;47(4):769-73

21. Warren S, Patel S, Kapron CM. The effect of vitamin E exposure on cadmium toxicity in mouse embryo cells in vitro. Toxicology. 1999;142(2):119-26

22. Paniagua-Castro N, Escalona-Cardoso G, Madrigal-Bujaidar E, Martínez-Galero E, Chamorro-Cevallos $\mathrm{G}$. Protection against cadmium-induced teratogenicity in vitro by glycine. Toxicology in vitro (TIV). 2008;22(1):75-9

23. Patra RC, Rautray AK, Swarup D. Oxidative stress in lead and cadmium toxicity and its amelioration. Veterinary medicine international (VMI). 2011

24. Maiga A, Diallo D, Bye R, Paulsen BS. Determination of some toxic and essential metal ions in medicinal and edible plants from Mali. Journal of Agricultural and Food Chemistry (JAFC). 2005;53(6):2316-21

25. Akinloye O, Arowojolu AO, Shittu OB, Anetor JI. Cadmium toxicity: a possible cause of male infertility in Nigeria. Reprod Biol (RB). 2006;6(1):17-30

26. Hew KW, Ericson WA, Welsh MJ. A single low cadmium dose causes failure of spermiation in the rat. Toxicol Appl Pharmacol (TAP). 1993;121(1):15-21

27. Saalu LC, Osinubi AA, Akinbami AA, Yama OE, Oyewopo AO, Enaibe BU. Moringa oleifera Lamarck (drumstick) leaf extract modulates the evidences of hydroxyurea-induced testicular derangement. International Journal of Applied Research in Natural Products. 2011; 4(2):32-45

28. Sreelatha S, Padma PR. Protective mechanisms of Moringa oleifera against $\mathrm{CCl} 4$-induced oxidative stress in precision-cut liver slices. Forschende Komplementärmedizin/Research in Complementary Medicine. 2010;17(4):189-94

29. Chandrasekar MJ, Bommu P, Nanjan M, Suresh B. Chemoprotective effect of Phyllanthus maderaspatensis. In modulating cisplatin-induced nephrotoxicity and genotoxicity. Pharmaceutical biology. 2006;44(2):100-6

30. Akunna GG, Ogunmodede OS, Saalu CL, Ogunlade B, Bello AJ, Salawu EO. Ameliorative effect of Moringa oleifera (drumstick) leaf extracts on chromium induced testicular toxicity in rat testes. World Journal of Life Sciences and Medical Research. 2012;2(1):20 
GRAPHICAL ABSTRACT

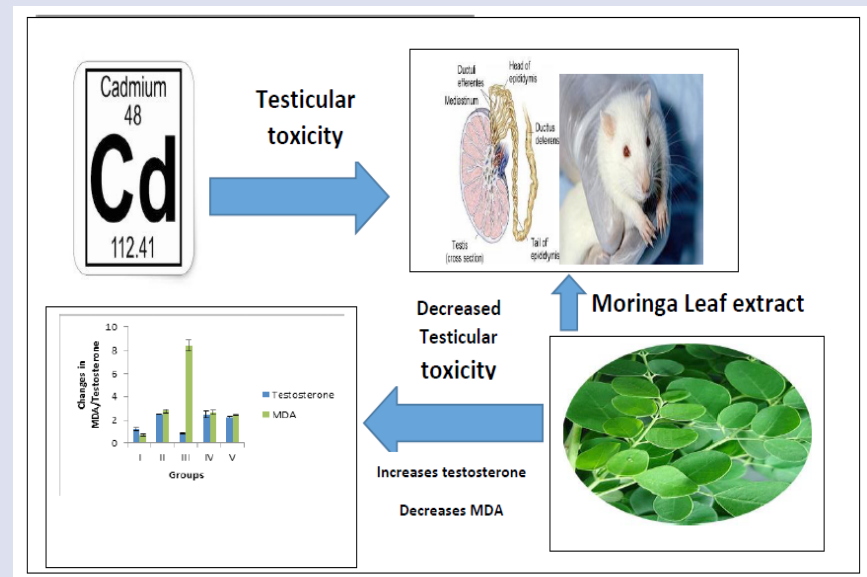

\section{SUMMARY}

- Cadmium (Cd) exposure produces testicular toxicity. The pre \& post treatment with aqueous leaf extract of Moringa olifera (MoE) showed a significant reduction in the testicular toxicity with pre-treatment response being better than post treatment. The decrease in the toxicity might be due to presence of antioxidants.

\section{ABOUT AUTHORS}

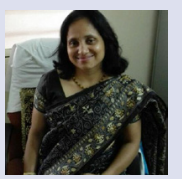

Dr.Vinodini NA: She has obtained her Ph. D. degree in 2005 from Manipal Academy of Higher Education Manipal, and currently she is working as Associate professor in the department of physiology Kasturba Medical college Mangalore Karnataka. Her field of research is toxicology, reperfusion injury and cancer and to find out preventive as well as therapeutic solutions from different plant sources. she has attended \& presented papers at international \& national level conferences and has received best paper award in an international conference organized by IISRO held at Pattaya. She has more than 40 papers to her credit. She has also been a member of Board of Studies (BOS) for BDS curriculum, Manipal-University (MU), Karnataka, India.

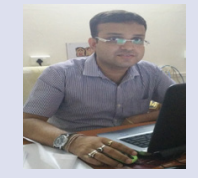

Dr. Pratik Kumar Chatterjee: He has obtained his MBBS degree from Manipal College of Medical Sciences (MCOMS), Pokhara, Kathmandu-University (KU), Nepal, in the year 2006 \& consequently MD (Physiology) from Kasturba Medical College (KMC), Manipal, Manipal-University (MU), Karnataka, India, in the year 2010. He also possesses Professional Diploma in Clinical Research (PDCR) from Catalyst Clinical Services Pvt. Ltd., Delhi, India, in the year 2013. Dr. Pratik Kumar Chatterjee is a Fellow of Association of General Education (FAGE), from Manipal-University (MU), Karnataka, India, from 2010 onwards. He is currently working as Associate-Professor, Kasturba Medical College (KMC), Mangalore, Manipal-University (MU), Karnataka, India. His field of interest is toxicology, diabetes \& cancer. He has attended \& presented papers at various national \& international conferences, Continued Medical Education (CME) programs, Workshops, Faculty Development programs \& has chaired sessions in Continued Medical Education (CME) programs also. He has been a member of Board of Studies (BOS) for MBBS curriculum, Manipal-University (MU), Karnataka, India, the year 2011 \& 2017 respectively. He has more than 20 papers to his credit \& has been awarded certicate of appreciation for contribution to research Manipal-University (MU), Karnataka, India in the year 2012, 2013, 2014 \& is a recipient of Ist prize in Audio-Visual Self Learning Material, Manipal-University (MU), Karnataka, India in the year 2015. Dr. Pratik Kumar Chatterjee has also been conferred with the 'Good Teacher Award', Kasturba Medical College (KMC), Mangalore, Manipal-University (MU), Karnataka, India, in the year 2016.

Cite this article: Chatterjee PK, Vinodini NA, Rashmi KS, Nayanatara AK, Shetty SB, Suman VB, Bhat R, Kunal. Pre and Post-Treatment Effects: Estimation of Serum Testosterone and Lipid Peroxidation Levels on Moringa olifera Extract Induced Cadmium Exposed Rats. Pharmacog J. 2017;9(6):846-9. 